

\title{
Caça aos espelhos: 0 potencial de significados que emerge em autorretratos de Vivian Maier"
}

\author{
Mirror hunting: the potential of the meanings that emerges from Vivian Maier's \\ self-portraits \\ Márcia Rodrigues da Costa** \\ Maria 0gécia Drigo ${ }^{* \text { *wa }}$
}

\begin{abstract}
Resumo: A fim de explicitar o potencial de significados de autorretratos de Vivian Maier, apresentam-se concepções sobre o ato fotográfico e sobre o ato de decifrar fotografias, na perspectiva de Flusser, bem como reflexões sobre o autorretrato, conforme Barthes e Dubois e, por fim, a análise de quatro autorretratos a partir da proposta de Flusser para decifrar imagens. A importância deste artigo para a comunicação está na possibilidade de aprofundar os conhecimentos sobre o potencial comunicativo de autorretratos.
\end{abstract}

Palavras-Chave: Fotografia. Autorretrato. Vivian Maier. Espelho.

\footnotetext{
*Uma primeira versão desse artigo, que apresenta resultados de pesquisa de pós-doutorado desenvolvida com apoio da CAPES, foi apresentada no Grupo de Trabalho Comunicação e Fotografia, no X Encontro de Pesquisadores em Comunicação e Cultura, na Universidade de Sorocaba - Uniso - Sorocaba, SP, nos dias 26 e 27 de setembro de 2016.

**Pós-doutoranda em Comunicação e Cultura na Universidade de Sorocaba (Uniso - bolsista Capes), doutora e mestre em Comunicação pela Universidade Metodista de São Bernardo do Campo e especialista em História e Historiografia de São Paulo pela Universidade Bandeirantes (Uniban).marciarcosta13@gmail. com.

***Doutora em Comunicação e Semiótica pela PUC/SP; pós-doutora pela ECA/ USP; docente e coordenadora do Programa de Pós-Graduação em Comunicação e Cultura da Uniso; coordenadora do Grupo de Pesquisa em imagem Midiática e Supervisora da pós-doutoranda Márcia Rodrigues da Costa.
} 
Abstract: In order to make explicit the potential of Vivian Maier's self-portraits meanings, conceptions are presented about the photographic act and the photography decipher act, from Flusser's perspective, as well reflections about selfportraits, according to Barthes and Dubois and, finally, the analysis of four self-portraits. The relevance of this paper for communication lies in the possibility of expand the knowledge of the communicative potential of self-portraits.

Keywords: Photography. Self-portrait. Vivian Maier. Mirror.

\section{Introdução}

Este artigo apresenta resultados de pesquisa que tem como tema o potencial comunicativo do autorretrato, a partir da produção fotográfica de Vivian Maier. Como objetivo geral, tencionase compreender o autorretrato enquanto uma modalidade de representação que engendra intenções do fotógrafo e do dispositivo. Como específicos, propõe-se explicitar as estratégias da fotógrafa Vivian Maier para a realização dos seus autorretratos, bem como desvelar o potencial de significados neles engendrados. Para este artigo, tomamos como corpus quatro deles.

Muitos dos autorretratos de Maier são produzidos em ambientes internos, como banheiros privados ou públicos, ou externos, registrando o movimento das ruas de Chicago e Nova York, notadamente na segunda metade do século XIX, inserida em uma modalidade visual que, em certa medida, expressava "a vida moderna, sua mudança, velocidade e alienação resultante" (LEDERMAN, 2012, p. 289). São, ao mesmo tempo, autorretratos e fotografias de ação de rua que mostram sua presença, sua marca na cidade. Se nos espaços fechados ela se fotografa geralmente só, na cidade registra-se também acompanhada de outros personagens urbanos, que aparentam ser desconhecidos seus.

Os autorretratos podem ser produzidos com sombras, reflexos, espelhos ou mesmo com o uso do disparador automático, 
como esclarece Dubois (2006). Maier os explora de um modo muito peculiar. Os autorretratos que serão analisados valem-se do espelho.

Para alcançar o objetivo proposto, apresentamos um breve panorama da vida da fotógrafa Vivian Maier; reflexões sobre o autorretrato e a construção de um campo de embate, lugar do eu e de outros que nele habitam e, em seguida, analisamos as estratégias da fotógrafa, valendo-nos também do mito da Górgona Medusa e do modo de produção de imagens vinculado ao noir, enquanto um dispositivo de ver. Para tratar de aspectos do fotográfico, utilizamos Barthes, Dubois e Flusser. Iniciamos com aspectos biográficos da fotógrafa.

\section{Sobre a Fotógrafa Vivian Maier}

Vivian Dorothy Maier, segundo Maloof, nascida em Nova York, em 1 de fevereiro de 1926, é hoje reconhecida no mundo como a babá fotógrafa, mas até a sua morte, nos anos de 1990, ela viveu na obscuridade (MALOOF, 2013). A obra dessa fotógrafa, conforme Fraia (2014), foi colocada ao lado da produção de Diane Arbus, Walker Evans, Garry Winogrand e Robert Frank, e ganhou notoriedade quando John Maloof, historiador e corretor de imóveis, comprou os negativos de Maier em uma casa de leilão, em 2007, na cidade de Chicago (EUA). Fraia, que entrevistou Maloof, conta que:

$\mathrm{Na}$ época, Maloof não sabia praticamente nada sobre fotografia, mas quando decidiu olhar de perto o que tinha em mãos (e era muita coisa), ficou impressionado. Estava ali, diante dele, um riquíssimo panorama social de Nova York e Chicago nos anos 1950 e 1960, um olhar cheio de empatia sobre crianças e mulheres, a vida de gente simples, a experiência dos afro-americanos na cidade, bêbados, vagabundos, a face de mármore de nobres senhoras vestidas com pompa, uma freira na sombra, um 
homem caído e centenas de autorretratos (FRAIA, 2014).

O historiador descobriu que, sem jamais passar por uma formação em escolas ou cursos de fotografia, Maier produziu mais de 100 mil imagens entre 1950 e 1990, coletadas em dezenas de países, principalmente nos EUA. Ao divulgá-las na internet, Maloof constatou o grande interesse de pessoas de várias partes do mundo em torno da vida e obra da fotógrafa. Foi então que começou a investigá-las.

Conforme consta no documentário Finding Vivian Maier, produzido por Maloof (2013), a fotógrafa aparentemente nunca se casou, não teve filhos nem nutriu muitas amizades. Considerada por muitos como uma pessoa excêntrica, reservada, misteriosa e dotada de grande talento para a fotografia, ela teve uma vida extremamente privada.

Maier nasceu na França e seus pais - ela francesa, ele austríaco - se separaram quando ela era ainda bebê. Teria vivido até a adolescência, ou início da vida adulta $^{1}$, na pequena cidade de Saint-Julien-en-Champsaur, onde começara a fotografar ainda pequena, paixão iniciada nos EUA, influenciada pela amiga da mãe, a retratista Jeanne Bertrand. Ao voltar para os EUA, atuou como babá profissional e fotógrafa até os seus últimos dias de vida. Ela, que costumava morar com as famílias com as quais trabalhava, acumulava muita coisa em seus aposentos.

Vivian carregava sua vida com ela. Guardava tudo trancado em caixas nos seus aposentos. Pilhas de caixas. Pilhas de jornais. Ela acumulou de tudo. Guardou cada pequena coisa que juntou ao longo da vida. Cheques de imposto de renda não descontados do governo, totalizando milhares de dólares, cupons, notas fiscais, folhetos, passagens de ônibus e trens, chapéus, sapatos, bolsas e casacos. Ela mantinha suas fotos, centenas de milhares delas, e cente-

1 Há informações contraditórias sobre a idade em que ela teria se mudado para os EUA, conforme nota-se nas fontes às quais recorremos Mallof $(2013,2014)$ e Fraia (2014). 
nas de gravações em película cinematográfica no sótão das casas onde vivia e trabalhava, separados do mundo por um armário trancado. As fotos, nunca mostradas a ninguém, eram reveladas no banheiro de seu quarto convertido em câmara escura (FRAIA, 2014).

Ela teria escolhido a função de babá por conta da liberdade para fotografar nas ruas, já que transitava muito pela cidade na companhia das crianças. Se ao mesmo tempo era uma companhia divertida, por outro lado, em algumas ocasiões, chegava a maltratar algumas das crianças das quais cuidou, conforme contam algumas delas (hoje adultos) no documentário sobre a sua vida.

Sem família e sem amigos, a babá fotógrafa desfrutou de tempo para deslocar por várias cidades do mundo, em meados do século XX (FRAIA, 2014). Apresentava-se, algumas vezes, usando nomes falsos, conta John Maloof(2013), que encontrou documentos em que ela assinava como V. Smith, B. Maier e variações como V. Meyer. Quando questionada sobre os falsos nomes, respondeu: "Sou uma espécie de espiã. Sou uma mulher misteriosa. " (MALOOF, 2013).

O livro organizado pelo historiador, Vivian Maier: uma fotógrafa de rua (2014) apresenta imagens produzidas em Chicago e Nova York, ao longo dos anos 50, de forma catártica, espontânea e sensível. Se manteve silêncio sobre si mesma, sua obra nos dá pistas de sua personalidade e identidade, como "[...] alguém que existe unicamente nas coisas que viu", escreveu Geoff Dyer (MALOOF, 2014, p. 8). Maier produziu muitos autorretratos ao longo de sua vida, tanto em ambientes internos quanto externos. Essa produção nos permite pensar a autobiografia construída de si mesma por meio de imagens.

O documentário Finding Vivian Maier revela que a fotógrafa tinha conhecimento da qualidade de seu trabalho e da necessidade de torná-lo conhecido. Segundo Maloof (2013), ela teria exposto esse desejo em uma carta encontrada junto com seus documentos, na qual pedia a um amigo, que trabalhava em um laboratório do 
pequeno povoado de Saint-Bonnet-en-Champsaur, que revelasse algumas fotos que ela produzira.

Sobre sua obra, foram lançados ainda os seguintes livros: Vivian Maier: Out of Shadows (CityFiles Press), biografia escrita por Richard Cahan e Michael Williams; e Vivian Maier: SelfPortraits (PowerHouse Books), organizado por Maloof, com Elizabeth Avedon. Segundo Fraia (2014), uma exposição com suas fotografias já passou por mais de dez países, e dois documentários, Finding Vivian Maier, dirigido por Maloof, em parceria com Charlie Siskel, e The Vivian Maier Mistery, produzido pela BBC e dirigido por Jill Nicholls, chegaram às telas dos cinemas e da TV.

Embora a internet esteja repleta de referências (reportagens, críticas de fotografia e artigos não científicos) sobre a produção fotográfica de Vivian Maier, no âmbito acadêmico, não encontramos muitas pesquisas sobre a sua obra. Entre as pesquisas encontradas nos bancos de tese das universidades brasileiras, está a dissertação de mestrado de Luís Fernando Frandoloso, intitulada Das mudanças nas práticas e processos fotográficos em função dos dispositivos tecnológicos: Uma análise da flânerie ao longo de três séculos, apresentada no Programa de Pós-Graduação em Comunicação e Linguagens, da Universidade Tuiuti, do Paraná (Curitiba), que aborda a produção de vários fotógrafos, incluindo Maier. Há ainda o artigo produzido como resultado de trabalho de conclusão de curso de Tuane Maitá, intitulado O enigma do tempo nas fotografias de Vivian Maier, também em 2015, no Centro Universitário Univetes, em Lageado (RS).

Assim, consideramos pertinente explorar a obra de Vivian Maier pelo potencial dessa produção fotográfica, notadamente por mostrar-se fértil para suscitar reflexões sobre o processo de produção de autorretratos. Esta é a tarefa a que nos propomos na pesquisa mencionada e, de modo particular, nesse artigo, com os quatro autorretratos selecionados, que registram uma caça aos espelhos. 


\section{Sobre a Fotografia e o Autorretrato}

Barthes (1984) afirma que ele só se interessava pela fotografia por 'sentimento'. Mas, partindo disso, seu propósito era adentrála, guiado pela máxima: "vejo, sinto, portanto noto, olho e penso. " (BARTHES, 1984, p. 39). Assim, com essa máxima vieram os conceitos de studium e punctum. Nas palavras de Barthes (1984, p. 45): "É pelo Studium que me interesso por muitas fotografias, quer as receba como testemunhos políticos, quer as aprecie como bons quadros históricos: pois é culturalmente (essa conotação está presente no studium) que participo das figuras, das caras, dos gestos, dos cenários, das ações."

Barthes explica que não encontrou uma palavra, em francês, para exprimir essa espécie de interesse humano. Em latim, ele encontrou a palavra Studium, "que não quer dizer, pelo menos de imediato, 'estudo', mas a aplicação a uma coisa, o gosto por alguém, uma espécie de investimento geral, ardoroso, é verdade, mas sem acuidade particular." (BARTHES, 1984, p. 45).

Reconhecer o studium é fatalmente encontrar as intenções do fotógrafo, entrar em harmonia com elas, aprová-las, desaprová-las, mas sempre compreendê-las, discuti-las em mim mesmo, pois a cultura (com que tem a ver o studium) é um contrato feito entre os criadores e os consumidores (BARTHES, 1984, p. 47).

Para Barthes (1984, p.48), “o studium é o campo vasto do desejo indolente, do interesse diversificado, do gosto inconsequente: gosto / não gosto, I like / I don't. O studium é da ordem do to like, e não do to love; mobiliza um meio-desejo, um meio-querer".

Ainda sobre o studium, o autor ressalta que se trata de um saber ou polidez que o torna capaz de encontrar o Operator, vivenciando as intenções que guiam suas práticas, mas sob o ponto de vista do Spectador. Nas suas palavras: 
Isso ocorre um pouco como se eu tivesse de ler na Fotografia os mitos do Fotógrafo, fraternizando com eles, sem acreditar inteiramente neles. Esses mitos visam evidentemente (é para isso que serve o mito) a reconciliar a Fotografia e a sociedade (é necessário? - Pois bem, é: a Foto é perigosa), dotando-a de funções, que são para o Fotógrafo outros álibis. Essas funções são: informar, representar, surpreender, fazer significar, dar vontade. E eu, Spectator, eu as reconheço com mais ou menos prazer: nelas invisto meu studium (que jamais é meu gozo ou minha dor) (BARTHES, 1984, p. 48).

O punctum, é o segundo elemento que vem para romper com o efeito do studium. Nas palavras de Barthes (1984, p. 46):

Dessa vez, não sou eu quem vou buscá-lo (como invisto com minha consciência soberana no campo do studium), é ele que parte da cena, como uma flecha, e vem me transpassar. Em latim existe uma palavra para designar essa ferida, essa picada, essa marca feita por um instrumento pontudo; essa palavra me serviria em especial na medida em que remete também a ideia de pontuação e em que as fotos de que falo são, de fato, como que pontuadas, às vezes até mesmo mosqueadas, com esses pontos sensíveis; essas marcas, essas feridas são precisamente pontos.

Ambos, o studium e o punctum, contribuem para a tarefa do espectador de decifrar fotografia, proposta por Flusser, uma vez que decifrar fotografias consiste em decifrar as condições culturais que impregnam a selva em que o fotógrafo adentrou. $\mathrm{O}$ studium permitiria um olhar panorâmico para esta selva, enquanto o punctum, aprofunda tal olhar, em sintonia com as experiências do espectador nessa selva. Nesse sentido, verificar como eles se configuram numa fotografia constitui uma estratégia de decifração dela. 
Sobre a produção de retratos e sua relação com o processo de construção de identidade, Barthes (1984) esclarece que tal processo pode ser explorado sob diversos aspectos, pois os retratos transformam o sujeito em objeto e, até mesmo, em objeto de museu. Neles encontram-se, conforme Barthes (1984), quatro imaginários e tal encontro instaura um verdadeiro campo de forças. "Quatro imaginários aí se cruzam, aí se afrontam, aí se deformam. Diante da objetiva, sou ao mesmo tempo: aquele que eu me julgo, aquele que eu gostaria que me julgassem, aquele que o fotógrafo me julga e aquele de que ele se serve para exibir sua arte." (BARTHES, 1984, p. 27). Neste sentido, torna-se quase impossível não construir um jogo de olhares numa fotorretrato, a não ser que o rosto assuma uma 'máscara', como menciona o mesmo autor. Com o jogo de olhares instaura um campo de embates entre o eu e o outro.

O retrato tem suas origens na arte e sua evolução acompanhou as novas ideias trazidas da ciência do século XX, que mudaram a concepção do eu, notadamente as teorias que difundiram a noção do eu que se fratura e visto como algo volátil e cambiante. "O retrato pictórico foi a forma habitual de representar a identidade através da imagem ao longo dos séculos, até a chegada da fotografia" (CATALÀ, 2011, p. 245). O quadro era considerado "um espelho perfeito", onde o retratado se via por meio "dos olhos do outro" e, por ser feito à mão, era resultado de um acordo entre modelo e pintor (CATALÀ, 2011, p. 245).

Enquanto fotografia, o autorretrato é uma modalidade de retrato que conjuga o objeto e o fotógrafo. E, como enfatiza Dubois (2006, p. 156), "é o único retrato que reflete um criador no próprio momento do ato de criação". Isto na verdade é paradoxal, conforme enfatiza o mesmo autor, pois parece impossível desenharse desenhando ou pintar-se pintando. O processo fotográfico rompe esta barreira por meio da instantaneidade do processo fotográfico, ao reduzir a duração do ato de captação e de inscrição e congelando essas duas instâncias da representação, num só ato.

Nas palavras de Dubois (2006, p. 343): 
O autorretrato é o modo por excelência, constitutivo, originário, quase ontológico da fotografia (qualquer fotografia é sempre um autorretrato, sem metáfora: imagem do que ela toma, daquele que a toma, e do que ela é, tudo isso ao mesmo tempo, num mesmo e só lapso de espaço e de tempo, numa espécie de convulsão da representação e por ela). Se existe de fato um lugar específico, quase em sua pureza, uma metáfora da fotografia por inteiro, como tal é o autorretrato.

Sobre o ato do autorretrato, Dubois (2006, p. 344) esclarece que "o ser deve manter simultaneamente a postura de sujeito e objeto. Para isso só dispõe, em princípio, de um único lugar e de um único instante, um só bloco de espaço-tempo a ser ocupado". Enquanto busca de uma identidade impossível, o mesmo autor explica que o autorretrato provoca a cisão do sujeito, a necessária perda de si, a ausência, o vazio e, para tanto, o fotógrafo recorre a ardis, a contorções e às maquinações com espelhos, sombras, disparador automático e outros.

$\mathrm{O}$ autorretrato sempre foi uma prática muito comum entre fotógrafos. O mesmo autor afirma que, na história da fotografia, os fotógrafos, em geral, em algum momento dispararam suas câmeras contra si mesmo. Vejamos como Vivian Maier empreende tais disparos.

\section{O espelho e o modo de fazer do fotográfico enquanto objetos da cultura}

O espelho enquanto objeto que permeia as relações entre as pessoas, no transcorrer do tempo, agregou sentidos e significados, ou seja, constituiu-se como objeto cultural. Tais sentidos sempre envolveram "uma configuração entre o sujeito contemplado e o 
espelho que o contempla" (CHEVALIER; GHEERBRANT, 2008, p. 396), que vêm constituindo-se desde os mitos. O espelho, em contos iniciatórios do Ocidente, segundo Chevalier e Gheerbrant (2008, p. 393), reflete "a verdade, a sinceridade, o conteúdo do coração e da consciência", tal como o sol, a lua, o outro ou a água. O escudo, por sua vez, segundo Chevalier e Gheerbrant (2008, p. 387), "é o símbolo da arma passiva, defensiva, protetora, embora às vezes possa ser também mortal", como o escudo/espelho, dispositivo que guia o mito da Gorgóna Medusa.

Desde Homero, segundo Toscano (2013), os mitos são relembrados e reescritos e as fantásticas e estranhas criaturas, neles presentes, não foram esquecidas. Elas ainda impregnam as artes, a psicanálise, a filosofia, bem como produtos midiáticos, em geral. Entre esses mitos, importa para o contexto desse artigo, o da Górgona Medusa. Neste mito há o herói Perseu e um monstro com um poder assustador e também uma cabeça decapitada, representada visualmente em Cabeça de Medusa, por Caravaggio.

Na etapa do mito, que corresponde à morte da Medusa, o herói valeu-se do escudo-espelho. Dubois (2006, p. 149), esclarece que "o ardil de Perseu será o remontar o espaço do olhar protegendo-o atrás do escudo polido, portanto, devolvendo para Medusa seu próprio olhar mortal, que vai repercutir no espelho que o herói lhe estende para atingi-la na volta". Assim, Perseu "substitui seu próprio olho, frágil e suscetível de petrificação pelo olho de bronze de seu escudo-espelho, ou seja, pelo próprio olhar de Medusa, cuja força assassina se volta instantaneamente contra ela." (DUBOIS, 2006, p. 150).

No mito da Medusa, o espelho atua como produtor de distância, que é exata, criadora e segura. O espelho, permitiu a Perseu, ver sem ser visto. Trata-se, portanto, de um dispositivo, cuja estratégia é a criação de distância. Pois, é ela, a distância, que:

[...] permite meditar não apenas no misterioso intervalo que se forma na passagem de um olho de uma irmã Greia 
para outra, mas também no intervalo indefinível entre a vida e a morte, o visível e o invisível, o ser e o não-ser, o real e a imagem, o corpo humano e corpo divino. Espaço que está em sintonia com o próprio lugar ocupado pelos monstros: afinal, estes sempre se dissimularam nos interstícios... (TOSCANO, 2013, p. 50).

Nas análises que seguem, veremos como a fotógrafa Vivian Maier, em seus autorretratos, valendo-se dos espelhos e driblandoos, produz distância, no sentido mencionado por Toscano (2013). Mas, antes, vale destacar aspectos da cultura visual reinantes no período, o fenômeno noir, quando a fotografa adentrava a floresta densa da cultura, nas ruas das cidades de Nova Iorque e Chicago, principalmente.

Segundo Peixoto (1987), as superfícies espelhadas eram instrumentos basilares do noir, como um fenômeno social espectatorial, que construiu uma maneira de ver a visão. O noir trouxe à cena a dramaturgia de olhar, o expiar pelas vitrines, pelos espelhos, pelas sombras. $\mathrm{O}$ enquadramento era realizado por um olhar investigativo, que é enviesado, permeado de desconfiança e descrença. As experimentações do outro - jogos de olhares - ocorriam com o olho em comunhão com a máquina, mas são olhares que mostram e escondem, espiam e são espiados.

O espelho, segundo Peixoto (1987, p. 56):

[...] permite ver sem ver visto, ver alguém que está atrás da porta, ver algo que está parcialmente encoberto. É através do revisor que o homem perseguido percebe o carro que o segue. O olhar pelo espelho é indireto. É uma maneira de ver, em locais fechados, a visão. É também um olhar de soslaio, de viés, que permite vigiar, observar furtivamente, para agir na melhor ocasião.

Segundo Philip Kemp (2011), as origens do noir remontam às sombras, aos ângulos e ao mundo paranoico do Expressionismo 
Alemão, de cineastas como Friedrich Wilhelm Murnau, com Nosferatu (1922) e Fritz Lang, com Metrópolis (1927). É a estética da iluminação chiaroscuro, ângulos inusitados, flashbacks, narração sobreposta em primeira pessoa. O filme O falcão maltês (1941) traz iluminação chiaroscuro e herói cuja personalidade oscila entre luzes e sombras. Destacam-se ainda a câmera subjetiva, com o ponto de vista do personagem, como em "Janela Indiscreta" (1953) e "Um corpo que cai" ou "Vertigo" (1958), bem como espaços confinados, claustrofóbicos, que influem na psicologia dos personagens, como "Festim diabólico" ou "Rope" (1948).

O modo de olhar construído pelo noir, conforme Ortegosa (2010), leva o fotógrafo assim como o detetive, o jornalista, o viajante, a observar, investigar, descobrir, informar, recolher dados, interpretar, buscar respostas. Enquanto isso, o espectador busca decifrar signos, indícios, reconstruindo um quadro daquilo que perceberam e observaram. A fotografia, por sua vez, estabiliza o sentido de desorientação dessas viagens dando significados aos gestos do ato de fotografar, os gestos de se deslocar, de olhar, de se aproximar do objeto a ser fotografado, de disparar o gatilho da câmera-arma.

Nesse período, o fotográfico de Vivian Maier vai ao encontro desse modo de produção de imagens, o que podemos conferir nas análises postas em seguida.

\section{Os autorretratos de Vivian Maier}

A tarefa que tentamos realizar a seguir, com os autorretratos de Vivian Maier, é a de decifrá-los, no sentido proposto por Flusser (2011, p. 50), para quem tal ato implica, "entre outras coisas, o deciframento das condições culturais dribladas." $\mathrm{O}$ ato de decifrar imagem demanda que o olhar vagueie pela sua superfície, olhar esse denominado scanning. "O traçado do scanning segue a estrutura 
da imagem, mas também impulsos no íntimo do observador. O significado decifrado por este método será, pois, resultado de síntese entre duas intencionalidades: a do emissor e a do receptor." (FLUSSER, 2011, p. 22). Esclarece ainda que o vaguear do olhar é circular, ele "tende a voltar para contemplar elementos já vistos. Assim o 'antes' se torna 'depois', e o 'depois' se torna 'antes'. O tempo projetado pelo olhar sobre a imagem é o do eterno retorno." (FLUSSER, 2011, p. 22).

Em relação ao gesto de fotografar, Flusser (2011, p. 56) esclarece que ele "é gesto caçador no qual aparelho e fotógrafo se confundem, para formar unidade funcional inseparável. O propósito desse gesto unificado é produzir fotografias, isto é, superfícies nas quais se realizam simbolicamente cenas. "Assim, observar os movimentos de um fotógrafo corresponde a observar o gesto de um caçador.

O antiquíssimo gesto do caçador paleolítico que persegue a caça na tundra. Com a diferença que o fotógrafo não se movimenta em pradaria aberta, mas na floresta densa da cultura. Seu gesto é, pois, estruturado por essa taiga artificial, e toda fenomenologia do gesto fotográfico deve levar em consideração os obstáculos contra os quais o gesto se choca: reconstruir a condição do gesto (FLUSSER, 2011, p. 49).

O mesmo filósofo esclarece que o fotógrafo está à caça de objetos culturais, portanto, de objetos que engendram intenções determinadas. Por isso mesmo, eles podem vedar ao fotógrafo a visão de caça. "E cada fotógrafo é vedado à sua maneira. Os caminhos tortuosos do fotógrafo visam driblar as intenções escondidas nos objetos. Ao fotografar, avança contra as intenções de sua cultura." (FLUSSER, 2011, p. 50).

Neste sentido, o gesto do fotógrafo é diferente, independentemente do local em que a caça ocorra, quer seja na selva de cidade ocidental, ou na cidade subdesenvolvida, ou na sala 
de estar, ou campo cultivado, como adverte Flusser.

Pois, nas fotos selecionadas, consideramos que o espelho é o objeto cultural perseguido e driblado pela fotógrafa e todos se valem de recursos fotográficos igualmente presentes no noir: a iluminação chiaroscuro, o preto e o branco, o uso de ângulos inusitados, bem como as superfícies espelhadas.

Neste sentido, considerando-se as ideias de Barthes já tratadas no item anterior, buscar o punctum, ou elementos que compõem o studium, pode contribuir para decifrar essas fotografias. O punctum, por ser algo que chama a atenção do espectador e que, após colocá-lo em estado de alerta, pode também incitá-lo a continuar a percorrer a imagem. O studium, por construir uma certa ambiência afetiva, permite ao espectador reportar-se a especificidades de uma determinada cultura, ou seja, pode chamar a atenção do espectador para os índices, para os vestígios dessa cultura que impregnam a imagem.

Vejamos como Vivian Maier ultrapassa ou evita o espelho de forma ardilosa. O espelho é um punctum na fotografia (Fig. 1).

Figura 1 - O espelho captura ao acaso: eu fugidio Fonte: Maier (2016).

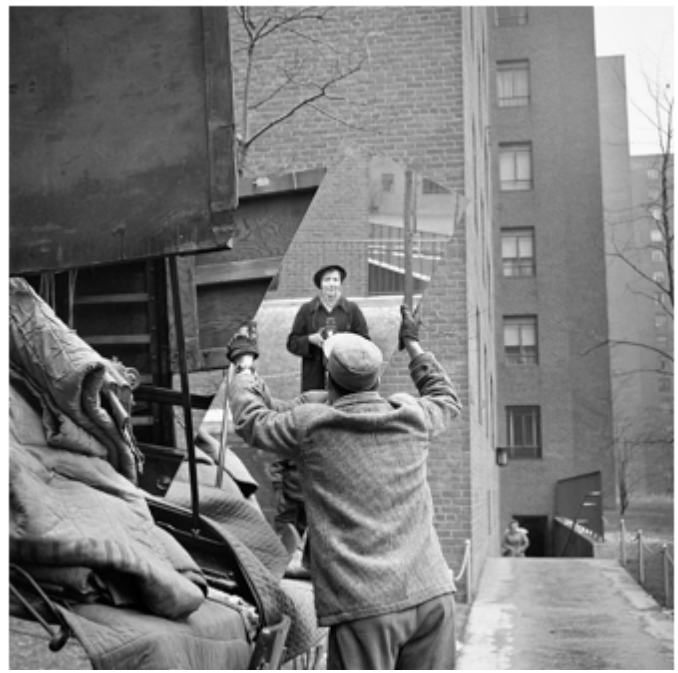


Lembramos que, conforme Barthes (1984), o punctum é como uma força de explosão. E como tal "se espalha, afeta, invade todo o campo" (DUBOIS, 2006, p. 78). Sob o efeito de tal força, após instantes de suspensão, o espectador pode caminhar com o olhar sobre a fotografia. É no lugar desse espectador/intérprete que nos colocamos agora. $\mathrm{O}$ espelho entra em cena disfarçadamente, ou seja, o acaso surpreende ambos, o espelho e a imagem por ele capturada. Com isso mina-se o campo de batalha que pode ser instaurado entre a superfície refletora e o objeto que se põe diante dela, no caso a fotógrafa Vivian Maier. O acaso desestabiliza, rompe com a atração/repulsão entre o espelho e o que se coloca diante dele. Eu não capturado, fugidio. Espelho que esmorece

Nesse caso, em relação à fotógrafa, pode-se dizer que ela zomba do espelho, por ser capturada, mas em um campo sem forças. Consegue, portanto, escapulir dele, o que significa que ela atinge o seu objetivo, que é fugir dos estranhos, dos diferentes que nela habita, pois como afirma Kristeva (1994, p. 190), "o estranho está em nós: somos nós próprios estrangeiros, somos divididos". $\mathrm{O}$ acaso faz do espelho seu escudo. Com esse movimento, como Perseu, ela se protege do olhar mortal da Medusa. Enquanto alguém se contempla, que vê sua imagem refletida, não se faz Medusa, pois dribla o seu próprio olhar.

O espelho novamente pode ser um punctum, na fotografia (Fig. 2).

Ele se mostra radiante, suntuoso e pronto para emoldurar, com requinte e sofisticação. Ao lado de outros objetos, tal como num quadro de natureza morta, no qual os objetos exibem as qualidades inerentes às suas formas, cores, texturas ou à combinação desses elementos, levando o espectador a percebê-los como inanimados, incitando-o à contemplação. $\mathrm{O}$ espelho na imagem apresenta-se despido de sua potência.

Ele atrai o olhar do espectador, que busca a imagem da fotógrafa (ou a sua própria imagem) nele refletida. Ela vence a batalha e o imobiliza, permitindo-lhe somente a captura de alguma 
coisa, mas de modo vago, impreciso. O espelho, incapaz de capturar a fotógrafa, explode em luz sob o olhar do espectador/observador. Luz que se espalha, que se difrata em busca dos diferentes, dos estranhos que nela (na fotógrafa) têm sua morada. Ela o observa com desconfiança, como um animal que espreita sua caça. A caçada faz-se cena. Eu ausente. Ou ainda, como Perseu que põe o escudoespelho à mostra, lança-o na captura do olhar de Medusa, mas ela foge e permanece à espreita.

Na fotografia (Fig. 3), o studium constitui-se com imagens refletidas por um espelho, aparentemente ausente. Ele constrói uma ambiência de leveza, um campo neutro, no qual a moldura aparentemente refeita pelo contorno de uma janela, torna questionável a presença do espelho. Essa ambiguidade contribui para que um campo neutro, sem embates, se atualize.

Figura 2 - Espelho capturado: eu ausente Fonte: Maier (2016).

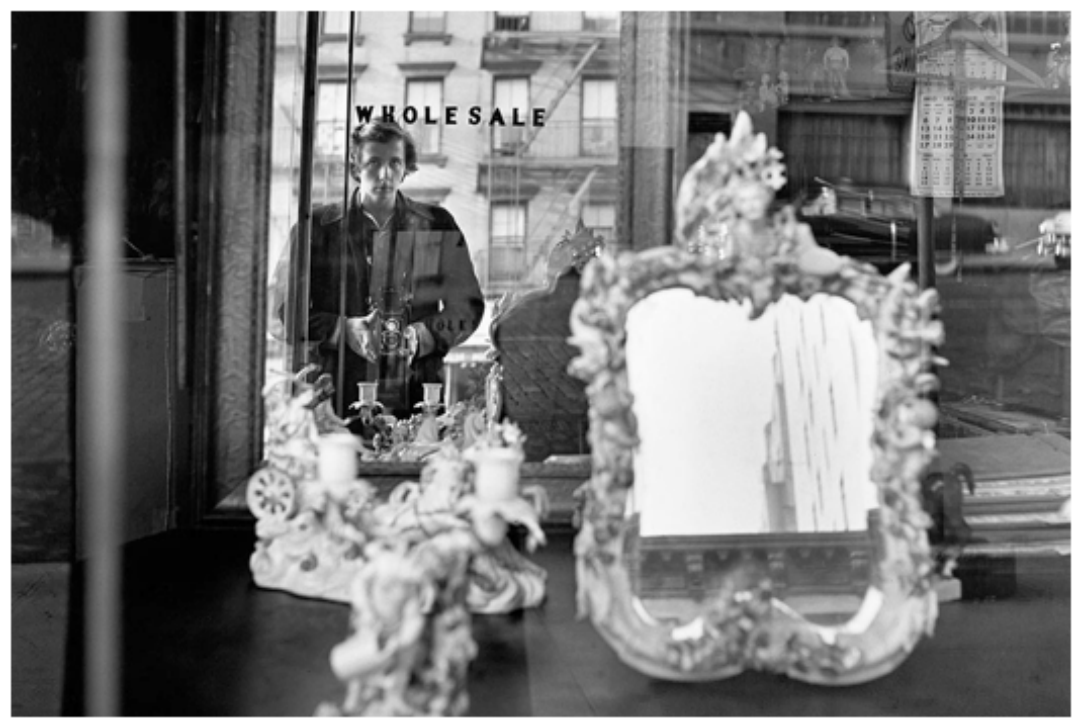


Figura 3 - Espelho passivo

Fonte: Maier (2016).

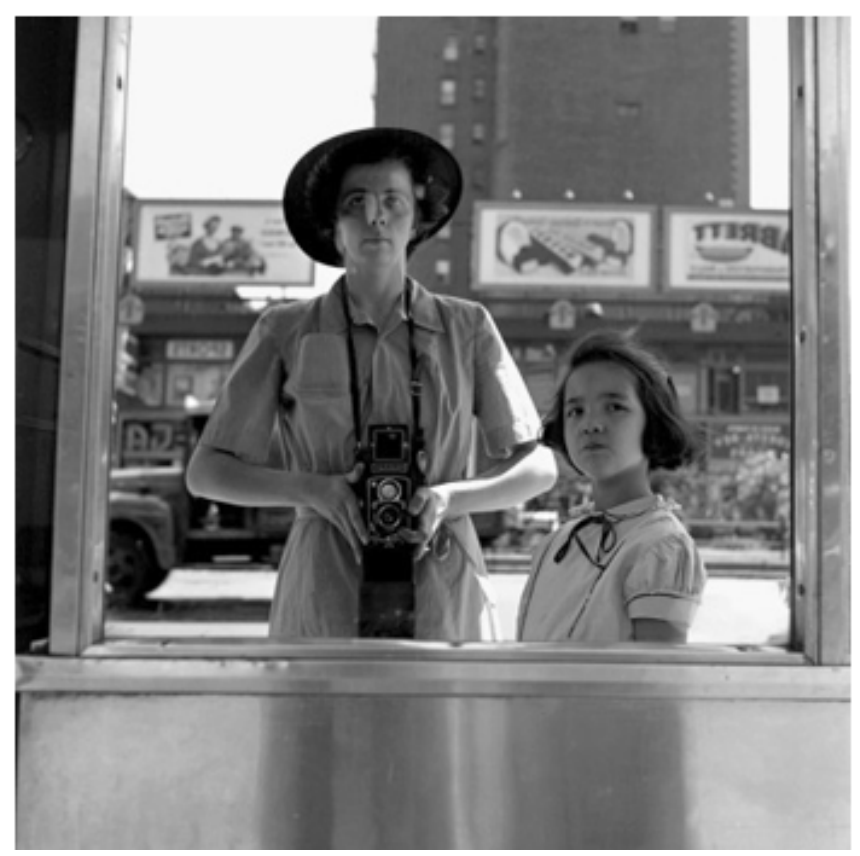

Conforme Peixoto (1987, p. 57), os jogos com os reflexos ocorrem também com a utilização de vidraças, que fazem as vezes do espelho. Assim, de um lado, devido a "transparência do vidro, não se sabe, a princípio, se este está do lado de fora ou atrás do detetive. Ele parece estar nos dois lugares ao mesmo tempo. É um ponto de referência enganoso, que desorienta sobre a verdadeira disposição do local". A sua imagem refletida, assim como esclarece Peixoto (1987, p. 57), é uma situação própria do mundo dos reflexos: "uma personagem inexistente, fruto da imaginação, literalmente ninguém, parece surgir e desaparecer, como um fantasma, dos múltiplos espelhos de um lugar tão irreal e onírico quanto ela". Maier espreita pelas sombras, com capa e chapéu, no figurino que lembra, ora o detetive, ora a fotógrafa e a caçadora. "Ao passar por 
outros, ao se disfarçar e se esconder nas sombras, ele [o detetive] se transforma num investigador." (PEIXOTO, 1987, p. 77).

Por outro lado, nesse espaço de sintonia, de cumplicidade, ambos entregam-se passivamente, há uma trégua. Nesse espaço não há possibilidade de que os estranhos que nela residam venham à tona, pois ela repete o gesto de Perseu, e enquanto Medusa, libertase do seu próprio olhar, num pacto com o espelho.

Por fim, no quarto autorretrato, o escudo/espelho de Perseu apresenta-se (Fig. 4).

Figura 4 - Escudo/Espelho: Viviam Maier e a nova Medusa Fonte: Maier (2016).

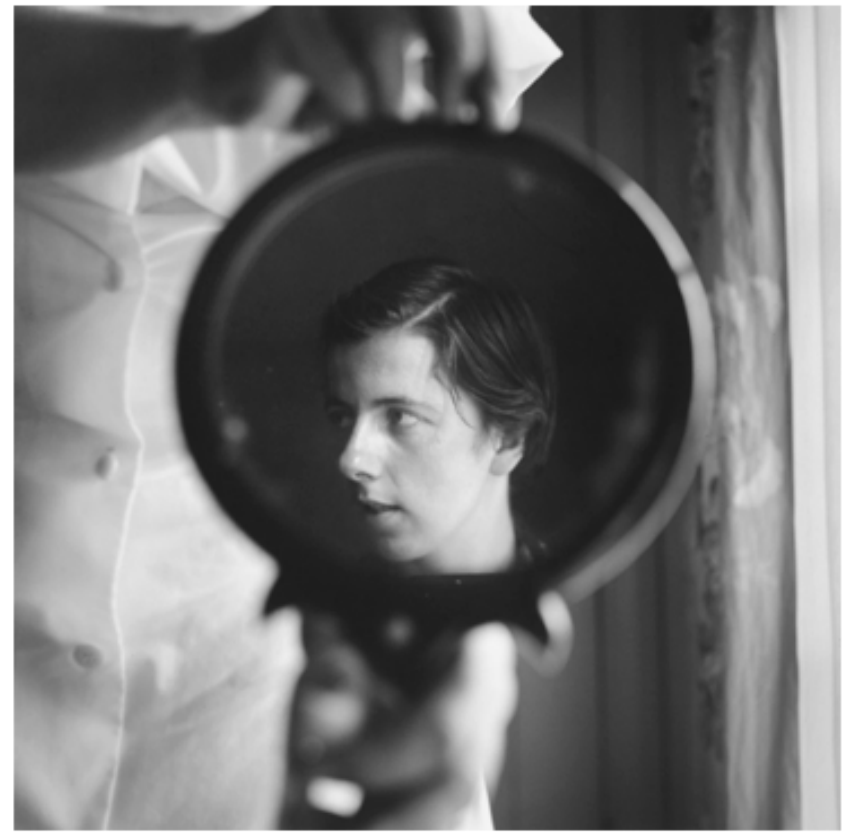

O punctum pode ser a moldura do espelho, agora de forma circular, que remete à Cabeça de Medusa, de Caravaggio. A imagem de quem sustenta o escudo está desfocada, o que põe ainda mais a forma do espelho - e o espelho - em destaque. É por ela, pela 
região delimitada por essa moldura, que o olhar do espectador pode adentrar a imagem. Há mãos desconhecidas que colocam o escudo e a nova Medusa à frente do olhar do espectador. A Medusa põe-se de perfil, com cabelos assentados, econômicos. O olhar é desviado do espelho, do espectador e dela mesma. Mas, ela os espia. Assim, foge dela própria e da morte. Nenhum pavor aparente, apenas um sorriso leve e sagaz, típico de quem reconhece que sua intenção será desvelada pelo espectador. Ela zomba assim do espectador que pode conjeturar sobre a possibilidade de que a autorretatada seja uma fotógrafa. Assim, Vivian Maier faz-se a fotógrafa sem dar chance ao espectador de adentrar sua alma, de identificar as múltiplas facetas da sua identidade.

Vivian Maier foge da morte ao entrar no jogo posto no mito, que é regido pelo dispositivo espelho/escudo. Nova Medusa. Esperta, astuta e conhecedora dos melindres que o espelho demanda. Nessa imagem, os significados culturalmente construídos por esse objeto são explorados pela fotógrafa. Ela foge da força paralisante do olhar de Medusa e, sutilmente, sem dizer quem é, faz-se fotógrafa.

\section{Considerações finais}

Assim, cumpre-se a jornada proposta por Flusser, a de que o fotógrafo deve mergulhar na floresta dos objetos culturais e driblar as suas intenções. Maier fez isso com o espelho e ao realizar tal tarefa mostra-se como fotógrafa, que é também espiã, caçadora, detetive.

O percurso de análise do autorretrato coloca em evidência a necessidade de decifrar imagens e a estratégia que sugerimos para tanto, a de observar os objetos da cultura que compõem a imagem. Uma vez observados faz-se necessário identificar o modo como este estabelece relações com os outros objetos que compõem a fotografia e, no caso, por ser autorretrato, principalmente com a 'imagem' do fotógrafo. Assim, a imagem, a 'cena' construída em uma fotografia, é vista como um campo de relações guiadas pelas 
intenções dos objetos e do fotógrafo.

Em relação aos conceitos de Barthes, constata-se que o punctum pode ser a porta de entrada, o fio que inicia o ato de decifrar. Tal ato é embalado também pela ambiência construída pelo studium. No entanto, aqui vale enfatizar a importância do studium ao fornecer indícios, novas pistas para que o ato seja levado adiante. Assim, há um ir e vir, um movimento no ato de decifrar, que conjuga o que foi abarcado pela imagem e o fora de campo. Se há um movimento cíclico no ato de decifrar, que parece ser construído com a retomada das pistas, como menciona Flusser, ele não é construído sem os sentidos e significados que vêm quando o olhar alcança o fora de campo, o não visível.

$\mathrm{Na}$ fotografia de Maier, a imagem refletida não seria apenas uma aparência viva, ou uma aparência ilusória, mas uma forma de nós e dela própria conhecermos a fotógrafa. Se o escudo/espelho, conforme Toscano, lembra que "espelho = logro", o reflexo também representa, segundo a autora, a relação entre a vida e a morte, o visível e o invisível, o ser e o não-ser, o real e a imagem, o corpo humano e corpo divino. Diante do espelho/escudo, Maier se imortaliza como fotógrafa e reclama a sua eterna presença. Aqui está o presente artigo que reafirma a sua intenção.

Com a continuidade da pesquisa e a exploração de outros ardis utilizados por Vivian Maier em seus autorretratos, como a sombra e outros mecanismos de reflexão da imagem, talvez possamos trazer à baila outros aspectos da intenção da fotógrafa.

\section{Referências}

BARTHES, Roland. A câmara clara: nota sobre fotografia. Rio de Janeiro: Nova Fronteira, 1984.

CATALÀ, Josep M. A forma do real: introdução aos estudos visuais. São Paulo: Summus, 2011. 
CHEVALIER, Jean; GHEERBRANT, Alan. Dicionário de símbolos: mitos, sonhos, costumes, gestos, formas, figuras, cores, números. Rio de Janeiro: J. Olympio, 2008.

DUBOIS, Philippe. O ato fotográfico e outros ensaios. Campinas: Papirus, 2006.

FLUSSER, Vilém. Filosofia da caixa preta: ensaios para uma futura filosofia da fotografia. São Paulo: Annablume, 2011.

FRAIA, Emilio. A descoberta do tesouro Vivian Maier.2014. Disponível em: <http://www1.folha.uol.com.br/ ilustrissima/2014/06/1469934-a-descoberta-do-tesouro-vivianmaier.shtml>. Acesso em: 13 jun. 2016.

KEMP, Philip. Tudo sobre cinema. Rio de Janeiro: Sextante, 2011.

KRISTEVA, Julia. Estrangeiros para nós mesmos. Rio de Janeiro: Rocco, 1994.

LEDERMAN, Erika. Fotografia de rua. In: HACKING, Juliet (Ed.). Tudo sobre fotografia. Rio de Janeiro: Sextante, 2012.

MAIER, Vivian. Self-portraits. Disponível em: <http://www. 
vivianmaier.com/gallery/self-portraits/\#slide-40>. Acesso em: 10 maio 2016.

MALLOF, John. Finding Vivian Maier. Direção de Charlie Siskel e John Mallof. EUA, 2013. 1:35:26s. Disponível em: <http://www. megafilmesxhd.net/a-fotografia-oculta-de-vivian-maier/>. Acesso em: 13 jun. 2016.

MALOOF, John (Org.). Vivian Maier: uma fotógrafa de rua. São Paulo: Autêntica, 2014.

ORTEGOSA, Marcia. Cinema noir: espelho e fotografia. São Paulo: Annablume, 2010.

PEIXOTO, Nelson Brissac. Cenários em ruínas: a realidade imaginária contemporânea. São Paulo: Brasiliense, 1987.

TOSCANO, Marta Alexandra. Imagem do tempo: os espelhos na arte contemporânea. 2013. 398 f. Tese (Doutorado em BelasArtes) - Universidade de Lisboa, Portugal, 2013. Disponível em: <repositorio.ul.pt/bitstream/10451/11255/1/ulsd068038_td_ Marta_Toscano.pdf>.Acesso em: 10 jun. 2016. 